\title{
Study on the Role of Folk Art in Cultivating Innovative Ability of Art Students of Higher Vocational Colleges
}

\author{
Nan Li \\ Jiangsu College of Engineering and Technology, Nantong Jiangsu, 226000
}

Keywords: folk art; art education; innovation

\begin{abstract}
Chinese folk art is an extremely rich and precious wealth created by our ancestors for thousands of years. It is a treasure of the country, a carrier of our national spiritual emotions, personality characteristics, cohesiveness and affinity, and a valuable art education resource. Excavating Chinese folk art is the spiritual resource and national foundation for the development of advanced culture, also an important source of national creativity as well as a solid foundation and effective way for inheriting, innovating and developing college art education in the new era.
\end{abstract}

\section{Introduction}

Chinese folk art has a long history and rich heritage. It is an intangible cultural heritage that best reflects the cultural characteristics of a nation or region. It inherits the simple and precious ancient culture of the nation and has a strong local flavor. It is the freest living art. Chinese folk art has its special styling system and artistic system with distinctive Chinese characteristics. Its unique charm of artistic creation has important implications for modern design art. With the rapid development and progress of China's economy and society, the return and redevelopment of Chinese folk art has become the trend of today's society, so it has broad and long-term social needs and prospects. The works, ideas, creative methods and aesthetic connotations of Chinese folk art are introduced into the art education of colleges and universities. On the basis of exploring, collecting, learning and studying the original ecological folk art, with the context of contemporary design, a new concept and new look combining Chinese folk art and modern art education is built through transplanting and learning from folk art, art fusion and integration.

\section{The Status Quo and Development Trend of Chinese Folk Art}

Chinese folk art is mainly produced and circulated among the people. It is the inheritance of the original cultural and cultural symbols of China and the source of all forms of art. It is the arts and crafts that the working people put into hand-made production to meet and satisfy their own needs and aesthetic requirements. It directly reflects the thoughts, feelings and aesthetic tastes of the working people and shows their wisdom and artistic talent. Similar to the most intangible cultural heritages in the world, with the acceleration of the urbanization process of industrial society, influenced by the economic and cultural integration of today's world, the people's minds are open constantly, and the soil on which folk art depends changes. The patterns and symbols of the original nationality were terminated, and the living environment of folk art was severely damaged. In particular, the original national folk art was rapidly disappearing. In recent years, as people continue to understand the artistic value and current situation of folk art clearly, the protection and inheritance of folk art has become a hot spot in society, and various protection measures and systems have been taken seriously.

As an art and culture reserve talent training library, the art colleges are the inheritance of culture and art as well as the study place of cultural and artistic heritage. Art education should bear the burden of national folk culture inheritance, and can cultivate new soil and new supporters for folk art. To make the whole society pay attention to the living environment of folk art and promote the sustainable development of folk art, we should practically strengthen the work of art education, comprehensively promote quality education, and cultivate new talents with innovative spirit and 
practical ability. Enhancing students' self-confidence and sense of responsibility and promoting the development of multiculturalism have become the trend of education reform and development. In teaching, we strive to achieve the differences and richness of students' understanding of national multiculturalism, to understand the characteristics of art, the diversity of artistic expressions and the unique contribution to social life, and to study the inner cultural spirit and externality of national folk art, to feel the cultural connotation of national folk art.

\section{Cultural Mission of Chinese Folk Art and Art Education in Higher Vocational Colleges}

Vocational college art design education is an integral part of the development of higher education in China today. Under the guidance of the scientific concept of development, vocational college art design education should be the base for cultivating talents and research protection through boldly borrowing and absorbing the experiences as well as the methods of different nationalities and regions. Folk art is a practical art created by the people. It generally has the characteristics of group, affinity and entertainment, and the cultural characteristics of customs and localization. In the education mode, we can adopt a multi-channel and multi-level model to cultivate talents of all types and levels with the ability to inherit, protect, develop, manage and research folk art. For example, in the colleges and universities, we can set up folk art research institutions, folk art exhibition halls, open folk-art majors, hold training classes, and open folk-art courses. In terms of curriculum, we can consider establishing a folk art theory course and appreciation course, setting up the introduction and experiential practice links of the intangible cultural heritage section with regional characteristics, setting up special lectures on folk art, and launching traditional craft practice courses. The campus introduces the website of ethnic folk culture and art. In May 2002, the Central Academy of Fine Arts established the "Intangible Cultural Heritage Research Center" and officially included folk art as an intangible cultural heritage in the university art education system. The Tianjin Academy of Fine Arts also set up the Wuqiang New Year Painting Research Office and held the Wuqiang New Year Painting Exhibition and academic seminars. The students of the Fine Arts Department of Guilin Teachers College also came into contact with different folk art in the annual art collection course, and they were inspired by folk art. They were shocked by folk art such as paper-cutting, embroidery, batik, clay sculpture, and have strong local culture. Content and unique expressions have become the source of their artistic creation. Going deep into the private sector to conduct artistic investigations with purpose, opportunity, method and basis leads the students to feel and understand the importance of folk art, and cultivates students' cultural personality and "cultural psychology" in essence, and enhances students' national culture aesthetic consciousness.

\section{Inheriting Chinese Folk Art, and Serving Art Education}

Under the guidance of the "Arts for Learning” approach, we should make extensive use of various curriculum resources outside the school, including art galleries, libraries, public museums and private museums, local cultural relics, artist studios and art workshops. The school works with art galleries, museums and communities to develop various forms of art education. Folk arts such as batik, embroidery, weaving, paper-cutting, root carving, and clay sculpture of ethnic minorities can be used as part of the school's art curriculum. The basic task of innovative education is to expand students' innovative thinking. While teaching students the art design knowledge, we must pay attention to the expansion of students' innovative thinking. It is not only the result of the integration of the imagery of artistic thinking and the logic of scientific thinking, but also the rational way of thinking, especially the aesthetic ability, individual performance and innovative design ability. Basic knowledge and technical training are not our ultimate goal, but the key is to cultivate students' design concepts and innovative abilities. Therefore, folk art is the foundation of Chinese modern art design. A great work with unique national characteristics is created by excavating Chinese folk art, paying attention to learning from folk art, establishing a modern art design concept of developing nationalization. 
The art of different nationalities constitutes the artistic characteristics of the nation. In the design, the visual elements of different ethnic groups should be widely applied, and the socialization of design culture will contribute to the development of folk art. College art design education should strive to inherit and carry forward our country's outstanding folk art, and cultivate a new generation of artistic talents to serve the society. Art design educators should actively explore, study and absorb the essence of folk art, and guide students to design works with local ethnic characteristics. The integration of Chinese folk art with modern art can enhance the appeal of folk art. The formation of a strong academic environment is not only the concern of the society, the importance of the school, but more importantly, the joint efforts and common efforts of all teachers and students. In education and teaching, we should pursue creativity, explore sincerity, change for innovation, and strive for innovation. Only in this way can we improve our quality and survive. With the development of society and the development of the times, folk art also needs inheritance and innovation. While innovation is not a source of no water, but a redevelopment and re-creation of traditional cultural heritage based on contemporary spiritual needs.

The reason why many works of art are successful is also the inheritance and reference of folk art. In the case of graphic logos, integration with modern art can enhance the appeal of folk art. For example, the Taiwanese Emblem of Hong Kong Phoenix Satellite TV borrowed the phoenix bird figure on the painted pottery, and used the unique "comfortable" structure of China. It reflects a simple cultural heritage, and the wings of the phoenix bird are very dynamic, the two opposites reflect the characteristics of modern media and are well received by the audience. Another example is the "Liu Shaohui Work Showroom" unveiled on the second floor of the Fine Arts Department of Guilin Teachers College. This is a highlight of Guilin's education and Guilin art circles. Professor Liu Shaohui combines the "beauty of beauty" of bronze with the quaint and decorative art tradition of Chinese folk, and enhances the inner spirit of the free and childlike lines of Western modern art master Paul Klee, forming a color and texture. The visual impact of interweaving and line-face combination gives nature a magical charm. The "Decorative Painting Reporting Exhibition" held in the exhibition hall of the Fine Arts Department is a demonstration by Professor Liu Shaohui combining basic training with social needs and practicing with new teaching methods. There are mural designs combining Dunhuang Feitian and Guilin landscapes. There are beautiful scenes of the two rivers and four lakes, as well as the auspicious patterns of the "God of the Gates" and the modern composition, the festive images of the folk paper-cuts, and so on. In the painting, students can see the creative process of inheriting folk art to decorative painting. In accordance with the rules, rules and techniques of aesthetics, we created and formed art forms with rich national characteristics, regional characteristics and aesthetic tastes, and inherited and developed folk art with extremely high cultural and artistic values. Therefore, in the process of school art education, teachers use folk art to guide the practice of school art education, understand and study folk art from the perspective of art anthropology, and creatively use regional folk art to make it impossible for local school art teaching. The valuable extra-curricular educational resources to expand the teaching space of school art education is an important topic that Chinese art teachers cannot avoid in the contemporary international environment.

The only way to reform the art design education of local colleges and universities is innovative education. Only by maintaining the integrity and coherence of its ecological structure and maintaining its relative independence can folk art form a benign interaction with the economic industry, making our folk art more profound, profound and splendid. As one of the important components of the world's multiculturalism, local culture has obvious regional characteristics and regional differences, and it contains extremely rich cultural heritage. Art education should be extended to the culture and art of all nationalities. In this aspect, it respects the independence of each nation's art development and the universality of its mutual influence. Art teachers must not only impart the knowledge of modern aesthetic innovation, but also have the responsibility and obligation to develop the educational resources of regional culture, and deal with the commonality and individuality of art elements and aesthetic responses in art education, so that school art education can be taught according to local conditions. It is not only local, but also open, making the 
teaching of school art education more distinctive.

\section{Conclusion}

Inheriting traditional culture, promoting local culture, spreading folk art, and promoting the spirit of democracy, serving art education is one of the missions of vocational college art education. It is related to the comprehensive development of students' cultural quality as well as the existence of cultural diversity of various ethnic groups around the world, and their mutual understanding and communication. The diversification of cultural education brings not only thinking but also the thinking about education itself. Our next generation is the successor of the cultural blood. Therefore, we should inherit the "art development", explore the historical and cultural connotations behind folk art, and explore the regional characteristics of folk art expression language and national art with a more macroscopic view. Educators can examine the future survival and development of national art from a broader perspective. We can only cultivate a new generation of art design talents with good scientific and cultural literacy, keen aesthetic ability, creative thinking methods and proficiency in this professional technical ability through the concept innovation, teaching innovation and management innovation of art design education.

\section{References}

[1] Luo Jiangfeng. Art Education——-The Channel of Developing National Folk Art [J]. Art Education, 2005, (6).

[2] Jiang Junlan. Talking about the Changing Trend of Folk Art [J]. Science and Technology Advisory Herald, 2007, (4).

[3] Jin Zhilin. On Chinese Folk Art [J]. Art Research, 2003 (3).

[4] Wang Guanying. Chinese Ancient Generation Folk Craft [M]. Beijing: The Commercial Press, 1997.

[5] Fang Xiangxia. Folk art [M]. Wuhan: Hubei Fine Arts Publishing House, 1999. 